Proc. Estonian Acad. Sci. Geol., 1999, 48, 1, 48-66

\title{
BIO- AND CHRONOSTRATIGRAPHY OF THE EARLY HOLOCENE SITE OF DOUBLE-STOREYED BURIED ORGANIC MATTER AT PAIKUSE, SOUTHWESTERN ESTONIA
}

\author{
Atko HEINSALU ${ }^{\mathrm{a}, \mathrm{b}}$, Siim VESKI ${ }^{\mathrm{a}, \mathrm{c}}$, and Tanel MOORA ${ }^{\mathrm{d}}$
}

a Institute of Geology at Tallinn Technical University, Estonia pst. 7, 10143 Tallinn, Estonia; heinsalu@gi.ee, veski@gi.ee

${ }^{b}$ Institute of Geology, University of Tartu, Vanemuise 46, 51014 Tartu, Estonia

c Institute of Earth Sciences, Quaternary Geology, Uppsala University, Villavägen 16, S-75236 Uppsala, Sweden

d Institute of History, Rüütli 6, 10130 Tallinn, Estonia

Received 6 October 1997, in revised form 21 January 1998

\begin{abstract}
Unique double-storeyed layers of buried organic matter at Paikuse, southwestern Estonia, were studied by means of pollen and diatom analysis and radiocarbon dating. The lower buried organic matter accumulated during the Pre-Boreal within c. 130 years. The Ancylus Lake transgression reached Paikuse after $9350 \mathrm{BP}$ and covered the peat with $1.5 \mathrm{~m}$ of sand. After the Ancylus Lake regression the upper organic matter accumulated, which was after about $7100 \mathrm{BP}$ covered by $1.5 \mathrm{~m}$ of sands of the Litorina Sea.
\end{abstract}

Key words: buried organic matter, pollen analysis, diatom analysis, radiocarbon dating, Ancylus Lake, Litorina Sea, Paikuse, Estonia.

\section{INTRODUCTION}

The investigated area is characterized by slow land uplift. Therefore the amplitude of transgressive sea level fluctuation has exceeded the isostatic land uplift, and numerous ancient peat, gyttja, and soil deposits are buried under either 
the Ancylus Lake or the Litorina Sea transgressive sediments. A unique sediment sequence with two buried organic layers separated from each other by a 1.5-m-thick sand layer is preserved on the left bank of the Pärnu River at Paikuse $\left(58^{\circ} 22^{\prime} 45^{\prime \prime} \mathrm{N}, 24^{\circ} 36^{\prime} 45^{\prime \prime}\right.$ E) (Fig. 1, Photo 1), close to the mouth of the Türgioja Stream, near Paikuse Police and Elementary Schools. It offers an excellent tool for palaeogeographical reconstruction of the Baltic Sea. The river bank is 7-8 m high, but only the upper part of it was studied. The site was found and first described by Thomson (1928). Kessel (1963) investigated by means of pollen analysis a similar sediment section, which she called Sindi, a few hundred metres upstream from Paikuse. Buried organic layers are found also at Lõpe, Kõdu, Urge, Pulli, Sikaselja, and Sindi (Fig. 1). The Pulli site has revealed the earliest traces of human activity in Estonia. It was inhabited by the Mesolithic hunters and fishermen around $9600{ }^{14} \mathrm{C}$ years ago (Jaanits, 1969; Selirand \& Tõnisson, 1984).

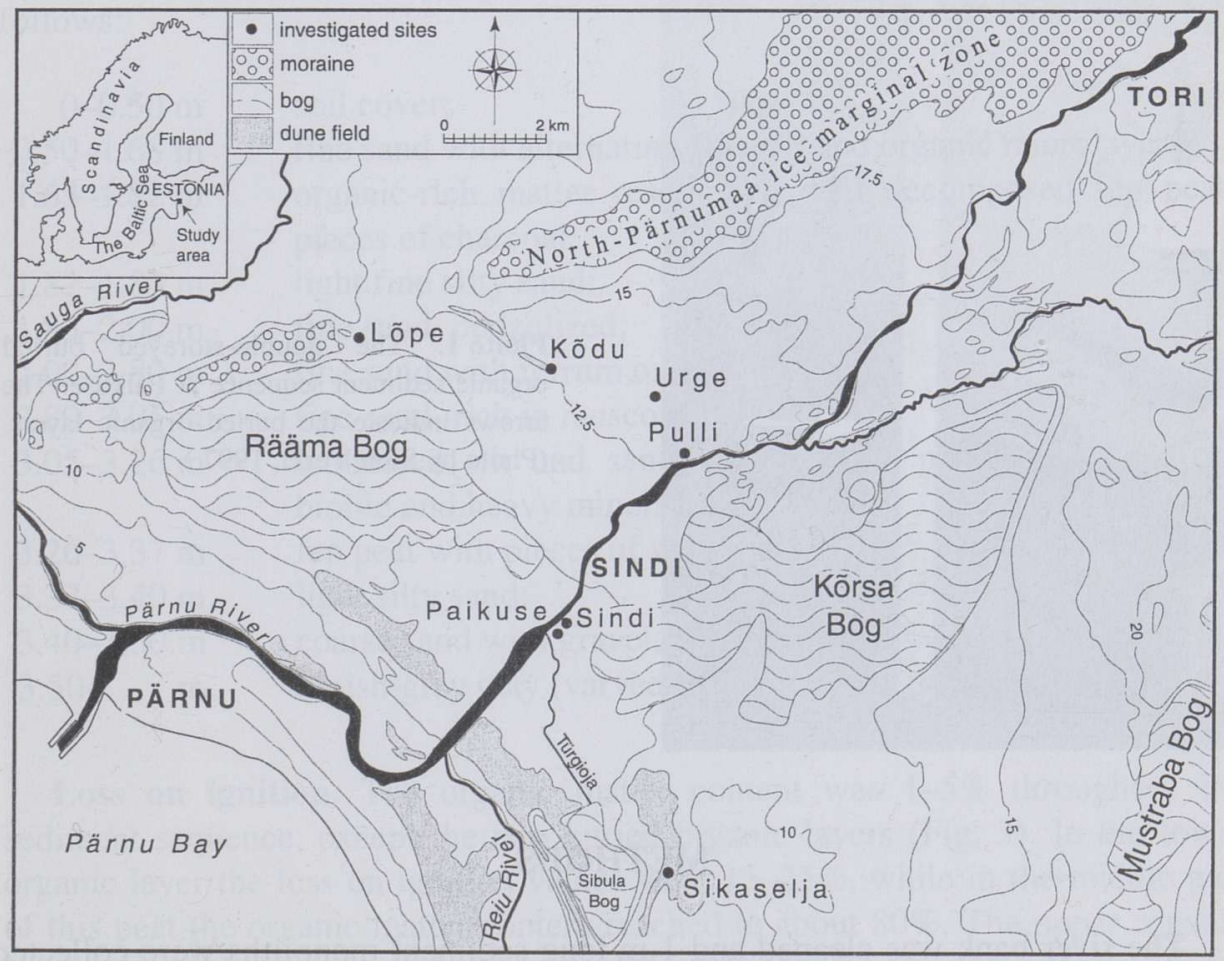

Fig. 1. Location of the study area. 


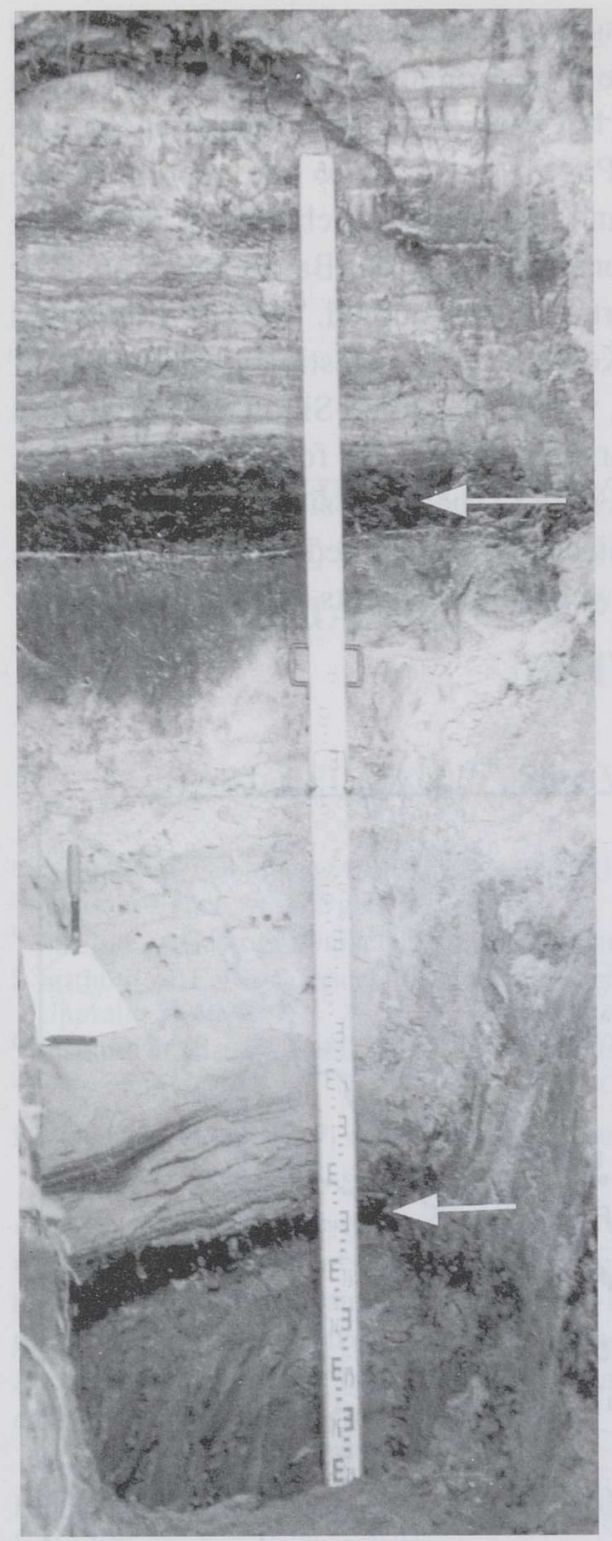

Photo 1. The double-storeyed buried organic sediment sequence at Paikuse. The arrows indicate the buried organic layers. (Photo by Siim Veski, 1997.)

\section{METHODS}

The river bank was cleaned and 1-m-long sediment monoliths were collected into wooden boxes and transported to the laboratory by T. Moora.

Preparation of diatom analysis followed the hydrogen peroxide method (Battarbee, 1986). Naphrax was used as the mounting medium, and analysis was carried out under the Zeiss Axiolab microscope with the magnification of $\times 1000$. 
Pollen preparation followed the standard procedure (Berglund \& RalskaJasiewiczowa, 1986). Pollen percentages were calculated as Arboreal Pollen $(\mathrm{AP})+$ Non-Arboreal Pollen $(\mathrm{NAP})=100 \%$; the percentages of other microfossils were calculated from their actual value plus this sum. The pollen and diatom diagrams were plotted with TILIA and TILIA GRAPH programs (Grimm, 1992).

The organic and $\mathrm{CaCO}_{3}$ contents in the sediment were estimated by loss on ignition at $550^{\circ} \mathrm{C}$ and $825^{\circ} \mathrm{C}$, respectively.

Samples for conventional ${ }^{14} \mathrm{C}$ (TA) dating were taken from the sediment monoliths and for AMS ${ }^{14} \mathrm{C}$ dating (Ua) from the wall of the cleaned sediment section. Radiocarbon dates are presented as uncalibrated ${ }^{14} \mathrm{C}$ years BP.

\section{RESULTS}

The sediment stratigraphy of the investigated sequence from the left bank of the Pärnu River at an altitude of $8.50 \mathrm{~m}$ a.s.l. (Fig. 2, Photos 1-3) is as follows:

$0-0.50 \mathrm{~m} \quad$ soil cover;

$0.50-1.68 \mathrm{~m} \quad$ fine sand with alternating fine silt and organic microlayers;

$1.68-1.82 \mathrm{~m}$ organic-rich matter resembling well decomposed fen peat, pieces of charcoal;

$1.82-1.83 \mathrm{~m} \quad$ light fine silty sand;

1.83-2.00 m fine sand, podzolized;

$2.00-2.80 \mathrm{~m}$ fine sand with ferrum oxide spots;

$2.80-3.05 \mathrm{~m}$ fine sand, rich in muscovite;

$3.05-3.26 \mathrm{~m}$ laminated silt and sand with organic microlayers, rich in biotite and heavy minerals;

3.26-3.37 $\mathrm{m}$ fen peat with pieces of wood;

$3.37-3.40 \mathrm{~m} \quad$ light silty sand;

$3.40-3.50 \mathrm{~m} \quad$ coarse sand with gravel;

$3.50+\mathrm{m} \quad$ bluish-grey clay (varved clay), hiatus at the upper border.

Loss on ignition. The organic matter content was $1-5 \%$ throughout the sediment sequence, except the two buried organic layers (Fig. 3). In the lower organic layer the loss on ignition values were $15-25 \%$, while in the middle part of this peat the organic matter content reached to about $80 \%$. The upper organic layer had the loss on ignition between $9 \%$ and $30 \%$. Due to the organic microlayers, the organic content above the upper organic layer slightly fluctuated under $5 \%$. The sediment sequence was characterized by a low carbonate content $(0.5-2.0 \%) . \mathrm{CaCO}_{3}$ increased up to $10 \%$ in the sands overlying, and in sand and clay underlying the lower organic layer. 
m a.s.l.

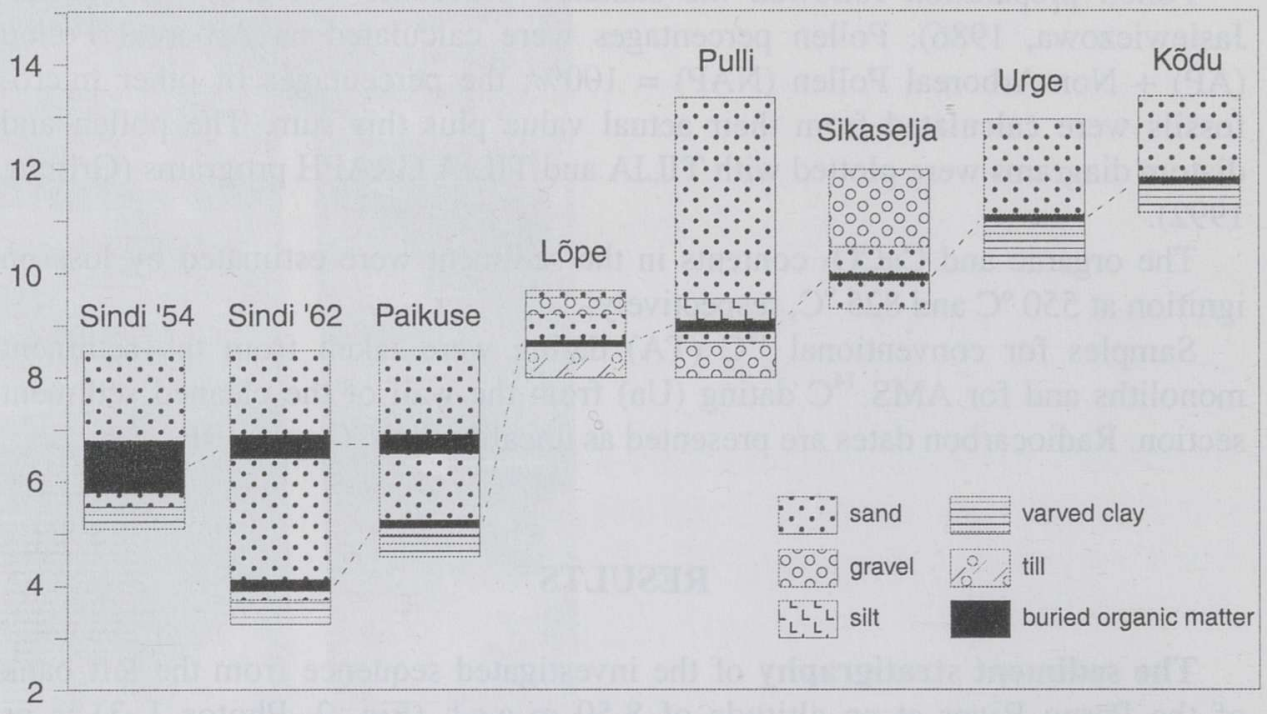

Fig. 2. The altitude and the lithology of the buried organic layers in the surroundings of Paikuse. Sindi ' 54 and Sindi ' 62 are the sediment sections investigated by Kessel (1963).

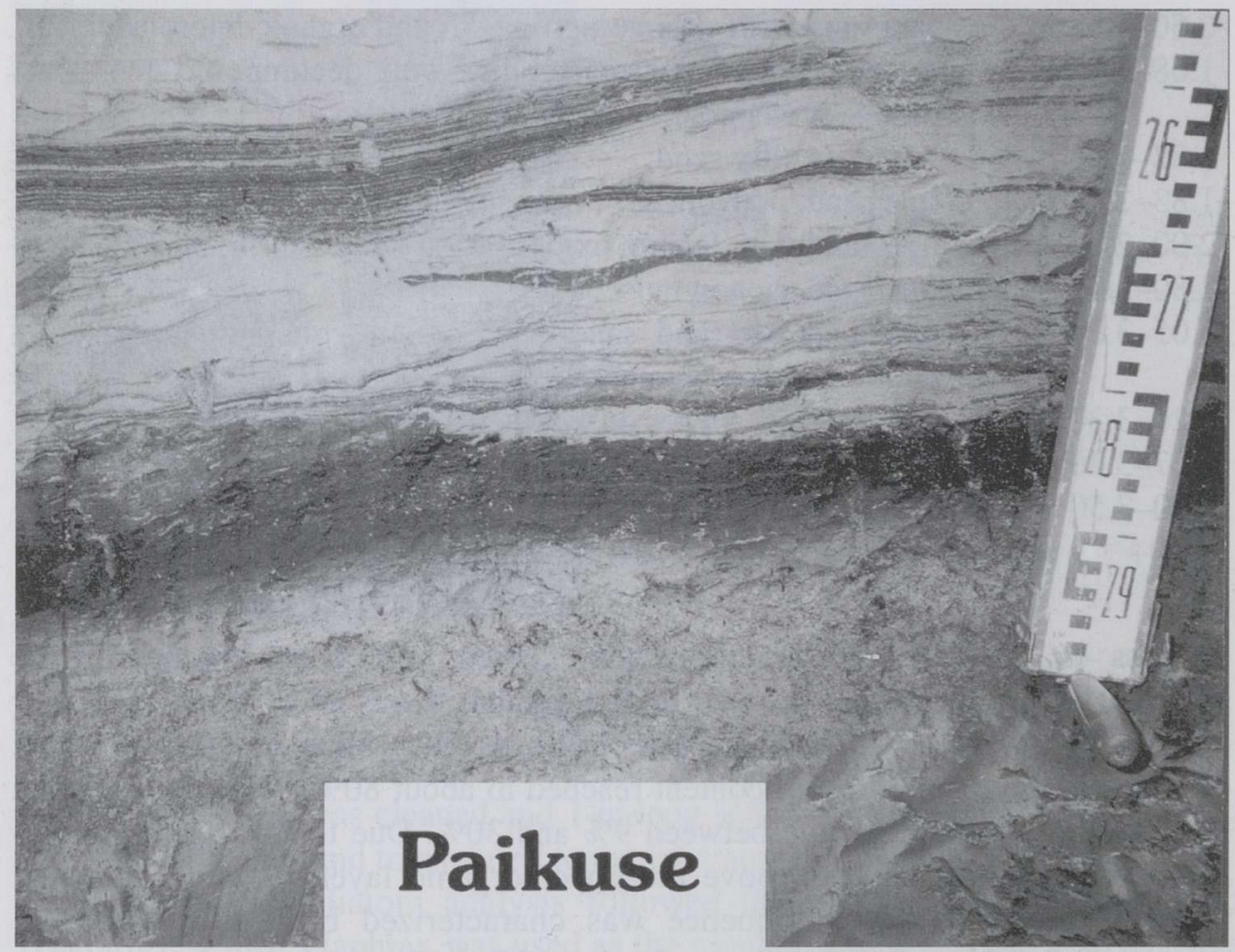

Photo 2. The lower part of the sediment sequence. (Photo by Siim Veski, 1997.) 


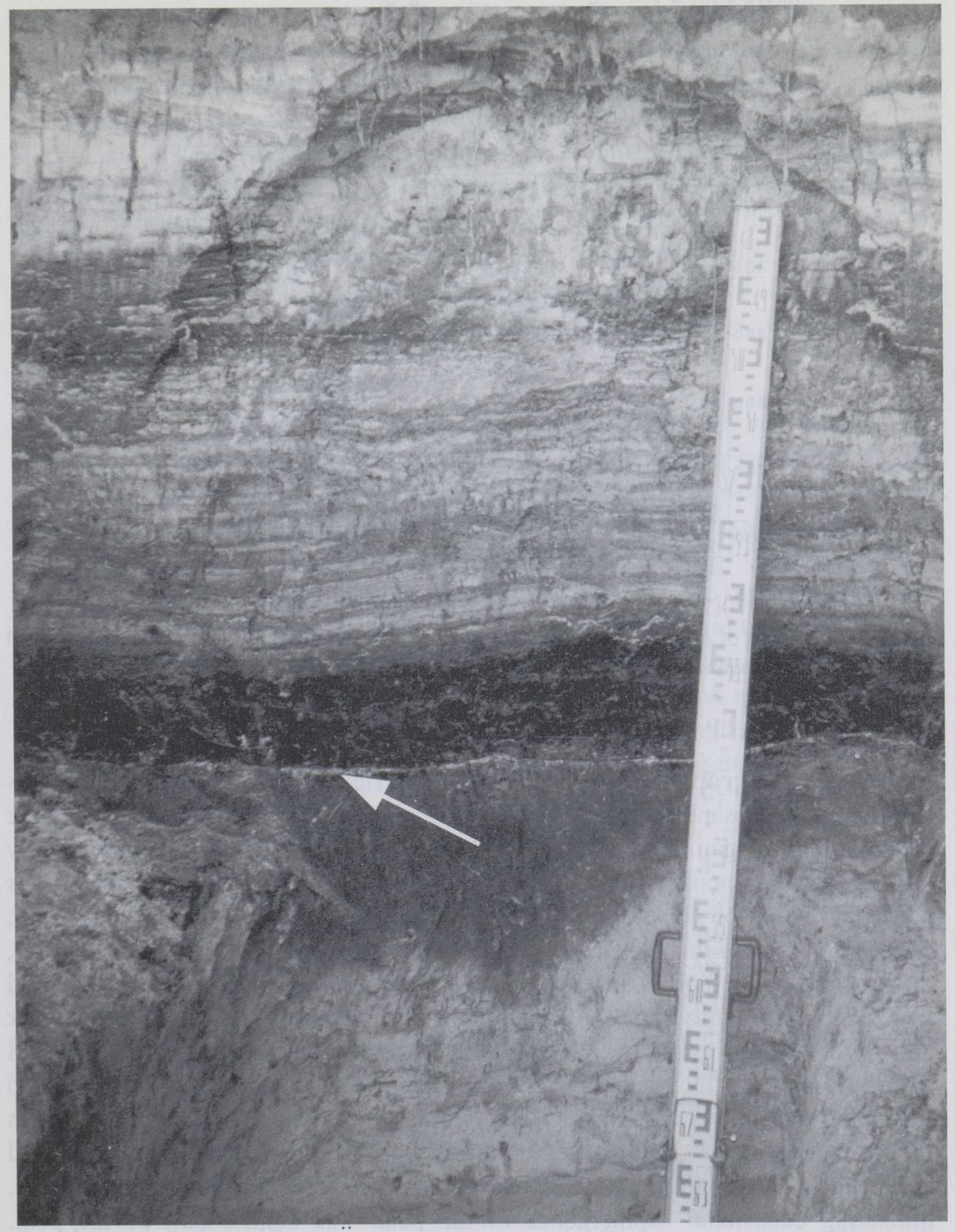

Photo 3. The upper part of the sediment sequence. The arrow indicates the thin sandy layer at a depth of $1.82 \mathrm{~m}$ under the upper buried organic layer. (Photo by Siim Veski, 1997.) 


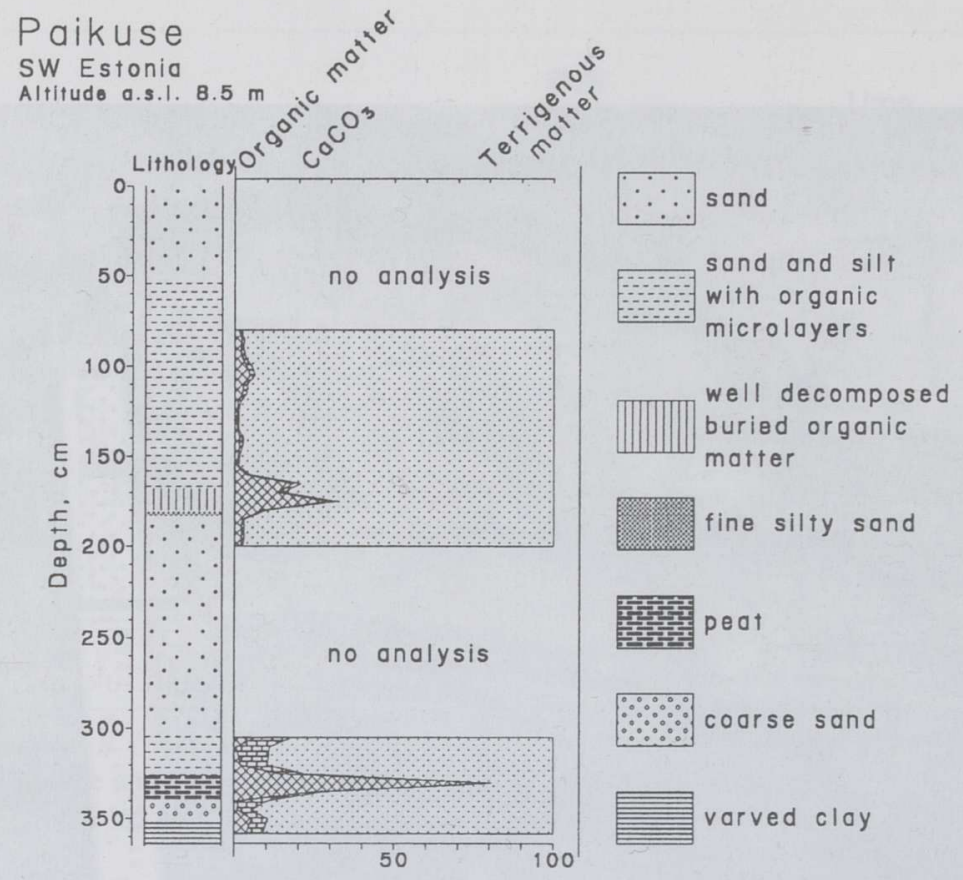

Fig. 3. The content of organic matter, $\mathrm{CaCO}_{3}$, and terrigenous matter (in \%) and the lithological description of the Paikuse outcrop.

Pollen stratigraphy. Pollen analysis was carried out from both organic layers and from the sands with organic microlayers (Figs. 4, 5). The organic sedimentation began around $9350 \mathrm{BP}$. The coarse sand between the varved clay and the peat contained no pollen, but abundantly seeds of Schoenoplectus lacustris. Seeds of Nuphar lutea, Potamogeton sp. (most probably P. natans), Menyanthes trifoliata, Carex spp., and Apiaceae were also observed (S. Hiie, pers. comm.). The pollen analysis of the peat showed a Salix-Betula dominated vegetation community. The microscopic material revealed several lumps of Salix and Betula pollen grains which had stuck together, suggesting their very local distribution and thus supporting closed growing conditions. This is also supported by the low amount of NAP. Similar very local growing conditions in the Pre-Boreal peats can be observed elsewhere (Veski, 1998). In the lower and upper parts of the peat, pollen grains of aquatic plants and algae are present, indicating occasional submergence of the peat. The central part of the peat, where the pollen grains are highly destroyed due to exposure to oxygen, shows no evidence of underwater conditions, but rather suggests relatively dry conditions. In the laminated silt and sand with organic microlayers overlying the peat, Betula and Pinus dominate. The share of NAP is high and is made up 
mainly of Poaceae (Phragmites) and Cyperaceae (Carex). The lithology and the pollen evidences suggest a periodically flooded near-shore environment.

The pollen diagram from the sands underlying the upper organic matter shows dominating Alnus and Betula. The NAP is low and the destruction degree high. In the upper organic layer itself, Pinus and Alnus dominate and the NAP appears abundantly. The latter is mostly represented as Poaceae and Cyperaceae, but other taxa, mainly indicative of a damp environment, such as Filipendula, Rosaceae, Apiaceae, Typha angustifolia/Sparganium, and Equisetum, occur. The degree of destruction is remarkably lower than in the sand. In the microlayered organic-rich sand above the upper organic layer, Pinus and Alnus dominate, the Quercetum Mixtum is rather stable, and NAP reaches up to 50\%. Aquatic pollen and algae are represented, of which Hystrix might show brackish-water conditions.

Diatom stratigraphy. The basal part of the sequence was bare of diatoms. The sand between 2.00 and $1.90 \mathrm{~m}$ contained mostly broken central areas and ends of the valves belonging to the genus Pinnularia which were impossible to identify to the species level (Figs. 6, 7). Aerophilous diatom taxa Pinnularia lata (Brébisson) W. Smith and Hantzschia amphioxys (Ehrenberg) Grunow, as well as the acidophilous diatom Eunotia praerupta Ehrenberg, are represented in low frequency. A lot of chrysophycean cysts and phytoliths occur at that level.

Hardly any diatoms were found in the upper organic layer, but some valves were recognized in the sand layer at a depth of $1.82 \mathrm{~m}$. The species indicating brackish-water conditions, such as Campylodiscus echeneis Ehrenberg, Campylodiscus clypeus Ehrenberg, Diploneis interrupta (Kützing) Cleve, and Diploneis smithii (Brébisson) Cleve, together with freshwater large-lake species Cocconeis disculus (Schumann) Cleve and Ellerbeckia arenaria (Moore) Crawford, as well as Pinnularia spp., were found.

At a depth of $1.66 \mathrm{~m}$, in the sand overlying the upper organic layer, diatoms appear again. In the interval of $1.66-1.40 \mathrm{~m}$ of the sand, freshwater large-lake taxa dominate. Of them, periphytic Cocconeis disculus, Navicula scutelloides W. Smith, Ellerbeckia arenaria, Epithemia adnata (Kützing) Brébisson, Epithemia goeppertiana Hilse, Epithemia turgida (Ehrenberg) Kützing, and Opephora martyi Héribaud are dominant. The share of brackish-water species increases regularly from $1 \%$ to $21 \%$. Among these Diploneis smithii, Diploneis didyma (Ehrenberg) Ehrenberg, and Campylodiscus echeneis are the most characteristic species. Further up in the sequence the brackish-water forms increase progressively and constitute up to $97 \%$ of the diatom assemblage. Diploneis interrupta is the dominant taxon. Diploneis smithii, Navicula peregrina (Ehrenberg) Kützing, and halophilous species Navicula pusilla W. Smith occur in moderate frequency. Freshwater diatoms almost disappear from a depth of $1.10 \mathrm{~m}$ and upwards. 


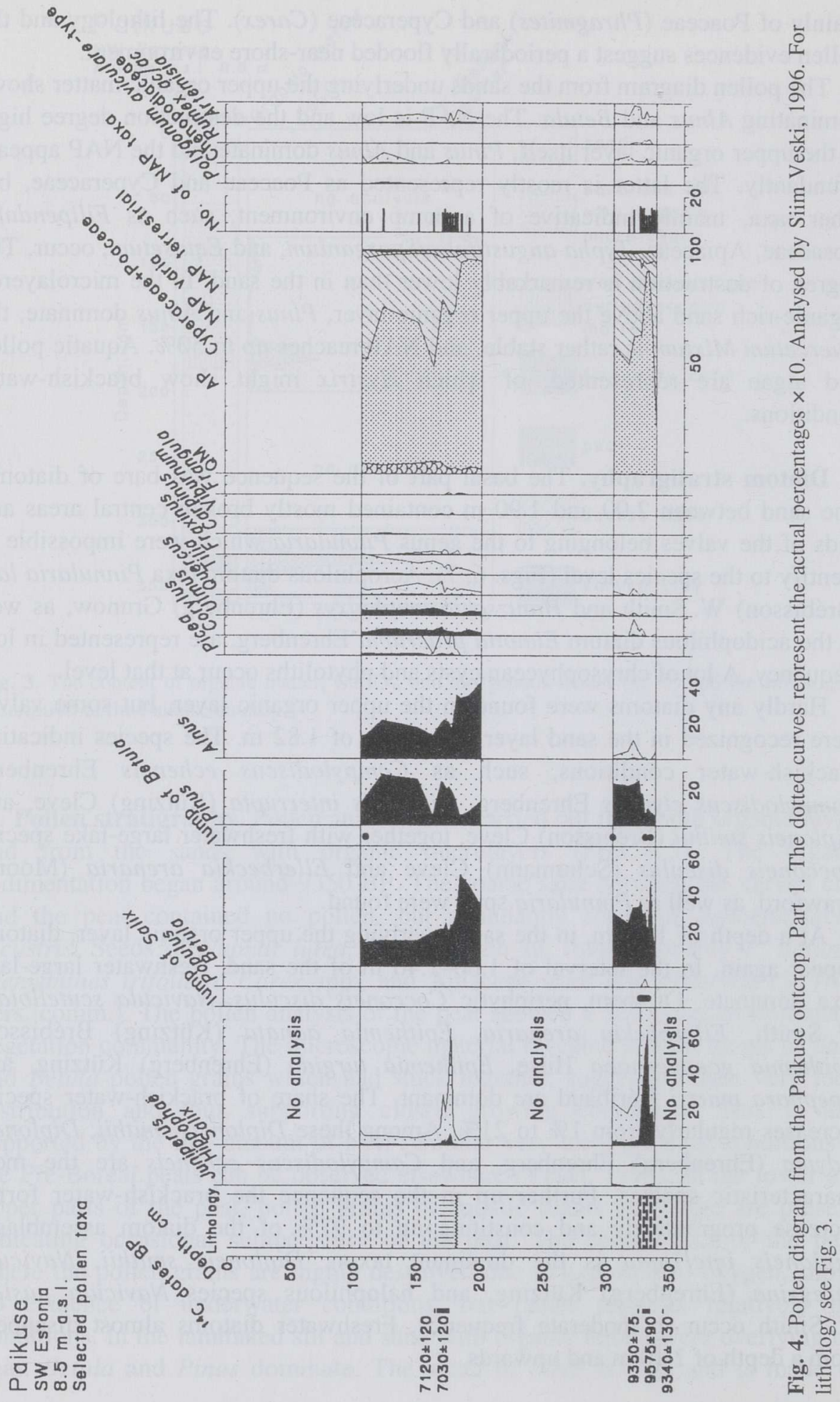




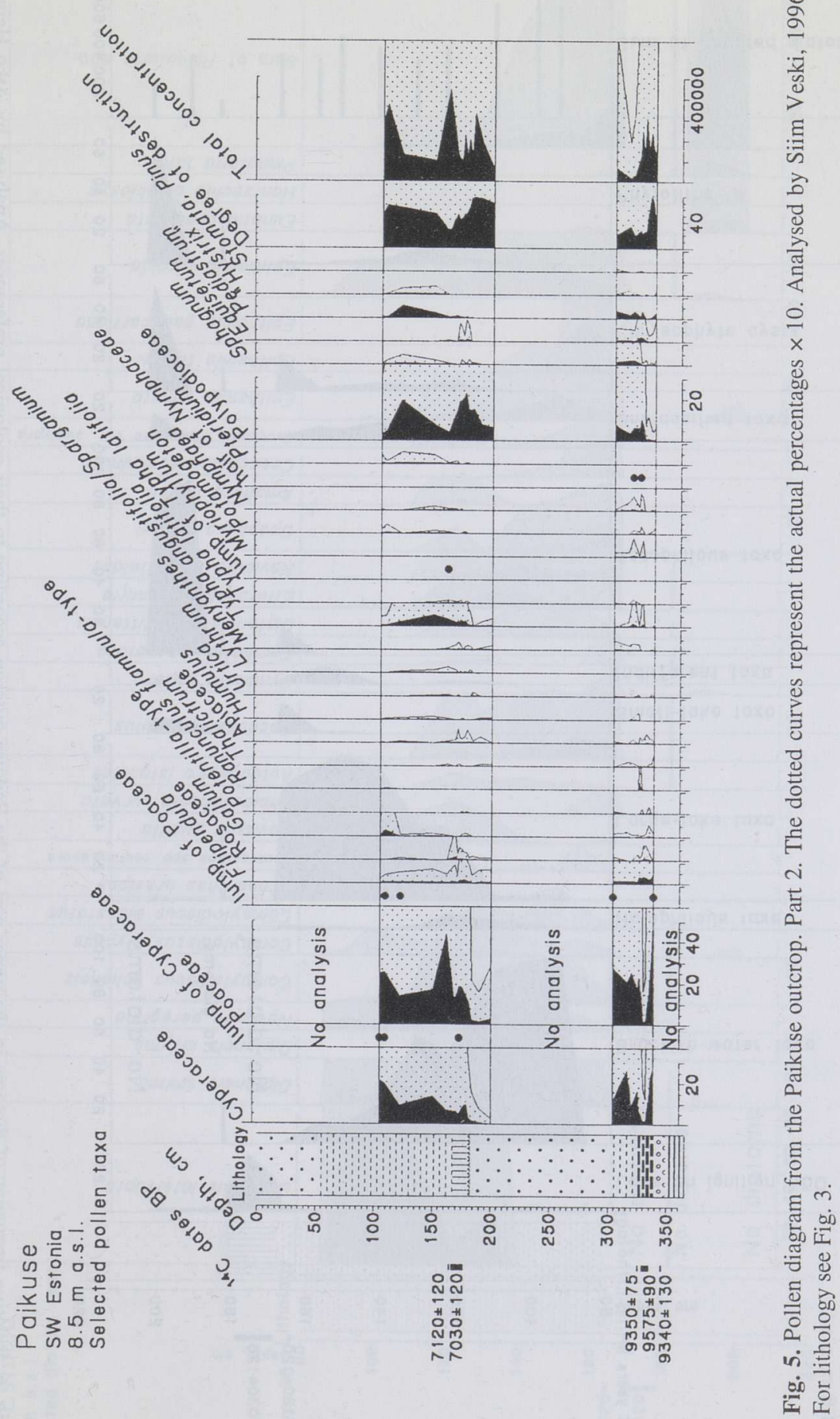




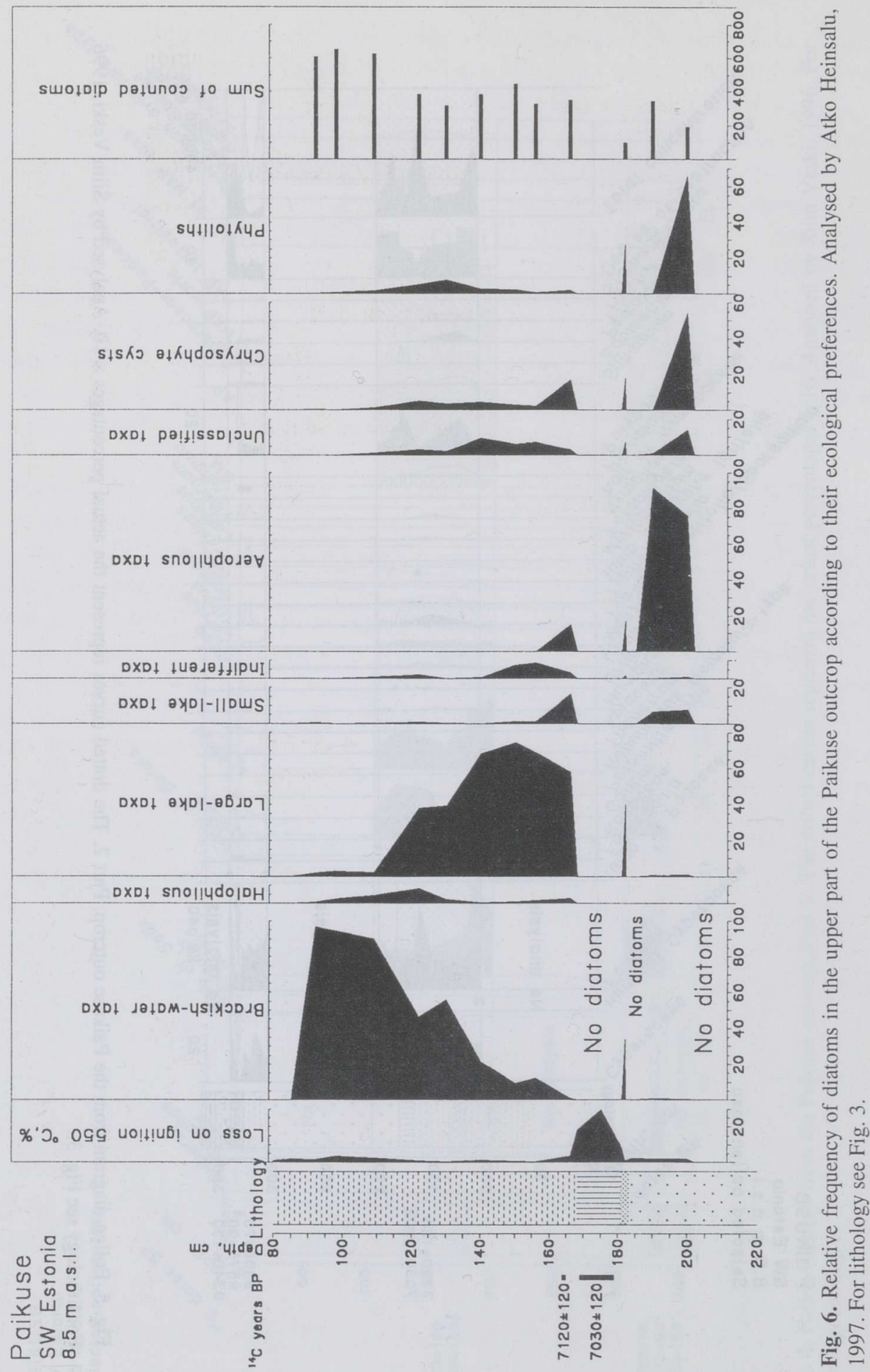




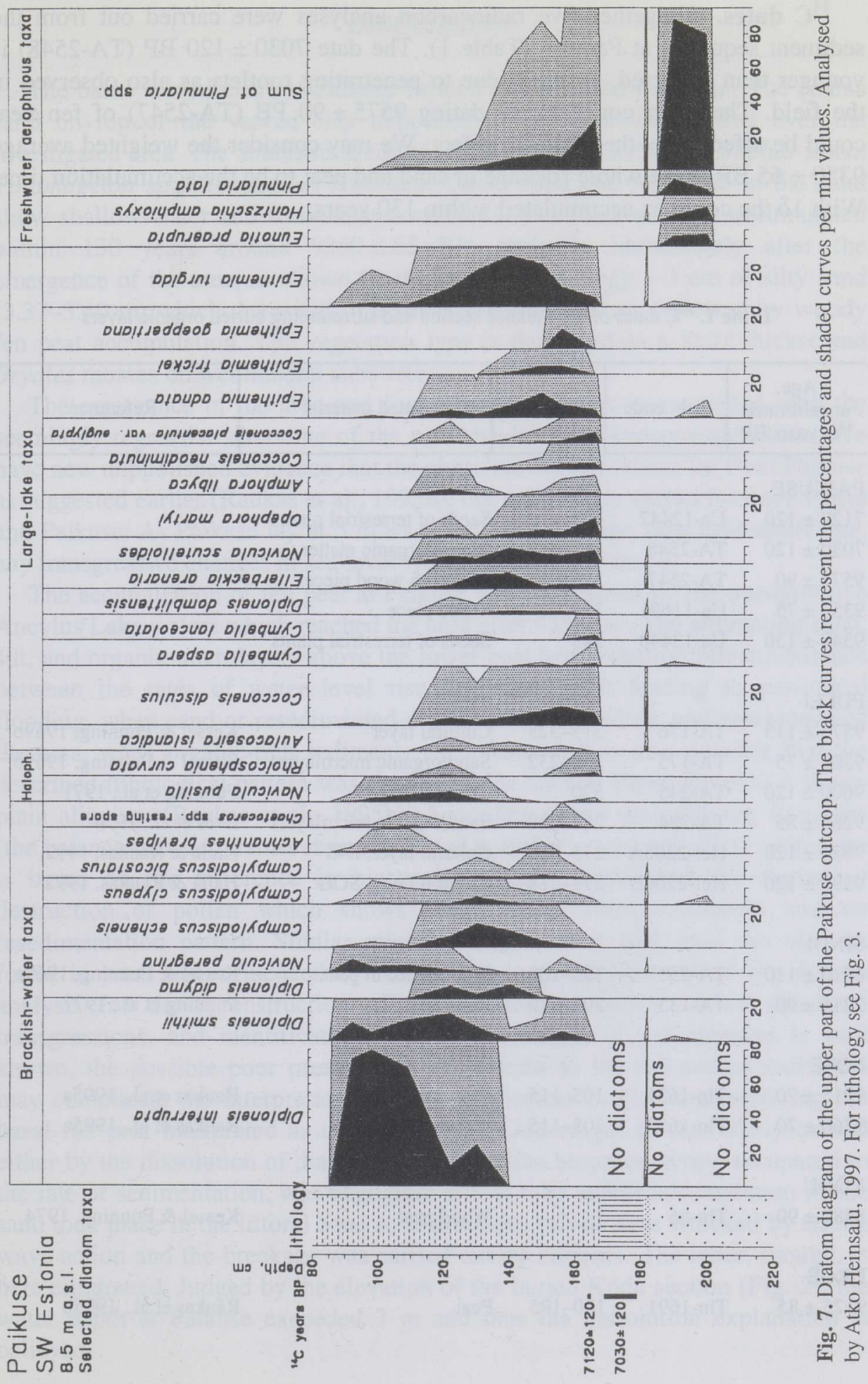


${ }^{14} \mathrm{C}$ dates. Altogether five radiocarbon analyses were carried out from the sediment sequence at Paikuse (Table 1). The date $7030 \pm 120 \mathrm{BP}$ (TA-2548) is younger than expected, probably due to penetrating rootlets as also observed in the field. The other conventional dating $9575 \pm 90 \mathrm{~PB}$ (TA-2547) of fen peat could be affected by the reservoir effect. We may consider the weighted average $9350 \pm 65 \mathrm{BP}$ of the whole package of sand and peat to be the accumulation time. With $1 \delta$ the complex accumulated within 130 years.

Table $1 .{ }^{14} \mathrm{C}$ dates of the Paikuse section and surrounding buried organic layers

\begin{tabular}{c|c|c|c|c}
\hline $\begin{array}{c}\text { Age, } \\
\text { uncalibrated } \\
{ }^{14} \text { C years BP }\end{array}$ & Lab. code & Depth, $\mathrm{cm}$ & Dated material & Reference \\
\hline
\end{tabular}

\section{PAIKUSE}

$7120 \pm 120$

$7030 \pm 120$

$9575 \pm 90$

$9350 \pm 75$

$9340 \pm 130$

PULLI

$9300 \pm 75 \quad$ TA-175

315-325

230-232

$9600 \pm 120$

TA-245

$9285 \pm 85$

TA-284

320

280-290
$9620 \pm 120$

Hel-2206A

$9290 \pm 120$

278-288

278-288

\section{SINDI}

$6710 \pm 110$

TA-55

$7215 \pm 90$

TA-133

LÕPE

$9215 \pm 70$

$$
\text { Tln-1631 }
$$

105-115

Peat

$9260 \pm 70$

195-202

300-310
Wood piece in peat

Reed peat

Seeds of terrestrial plants

Buried organic matter

Peat with wood pieces

Wood piece

Seeds of terrestrial plants

KÕDU

$8480 \pm 90$

Tln-66

$?$

Wood peat

URGE

$9125 \pm 85$

Tln-1691

180-195

Peat

Kessel \& Punning, 1974

Kessel \& Punning, 1969b

Kessel \& Punning, 1969b

Punning et al., 1971

Ilves et al., 1974

Haila \& Raukas, 1992

Haila \& Raukas, 1992

Kessel \& Punning, 1969a

Punning et al., 1977

Raukas et al., 1995a

Raukas et al., 1995a

Raukas et al., 1995b 


\section{DISCUSSION}

The basal varved clays at Paikuse formed in the Baltic Ice Lake. The coarse sand on top of the varved clay deposited as the shoreline shifted over the investigated area. The abundant seeds of Schoenoplectus lacustris, Nuphar lutea, Potamogeton sp., Menyanthes trifoliata, Carex spp., and Apiaceae in the sand show shallow-water and freshwater conditions. The sand and peat accumulated within 130 years around $9350 \pm 65 \mathrm{BP}$, probably immediately after the emergence of the area, as shown by the isolation lithology $-3 \mathrm{~cm}$ of silty sand (3.37-3.40 m) which deposited in a small isolation hollow, followed by woody fen peat accumulation. The vegetation type is described as a Salix thicket and Bryales mosses on wet mineral substrate.

The emergence of the area and formation of the peat is connected with the seemingly regressive shoreline of the pre-Ancylus Lake transgression time. We have new unpublished evidence that the shoreline did not retreat far from Paikuse as suggested earlier (Raukas et al., 1995b), but more likely stayed between Pärnu and Paikuse. As Paikuse lay at $5 \mathrm{~m}$ a.s.l. and almost on the zero land-uplift line, any transgressive changes in sea level would inevitably affect it.

The accumulation of fen peat at Paikuse was interrupted by the transgressive Ancylus Lake waters which reached the area after 9350 BP. The alternating sand, silt, and organic microlayers above the lower peat bed probably reflect a balance between the rates of water level rise and land uplift leading to periodical flooding, when sand or resedimented organics was deposited, and emergence of the area, when organic-rich sediments were formed. It is also possible that the described lithological pattern was created by the ancient Pärnu River as a floodplain alluvium (Raukas et al., 1995b). According to our material, the first idea (the balance between transgression and land uplift) is prioritized. This judgement is based on the difference in biostratigraphical material and the degree of destruction of pollen which shows better preservation conditions and no resedimentation pattern. Similar microlayering of peat and sand can also be found in areas not influenced by rivers. Although the potential of the diatom analysis for the reconstruction of past shorelines, indication of sea level transgressions, and identification of the environment of palaeobasins is well known, the possible poor preservation of diatoms in the calcareous sediments may complicate the interpretations. Lack of diatoms in the sand overlying the basal fen peat interpreted as of the Ancylus Lake origin is very likely caused either by the dissolution of diatom frustules, or the bioproductivity, compared to the rate of sedimentation, was negligible at that time and/or accumulation of the sand took place in the littoral zone so that diatom valves were wrecked by strong wave action and the breakage was carried out by currents. The latter, though, is here eliminated. Judged by the elevation of the buried Kõdu section (Fig. 2), the water depth at Paikuse exceeded $7 \mathrm{~m}$ and thus the dissolution explanation is believed. 
The first diatoms were recorded at a depth of $2 \mathrm{~m}$ under the upper organic layer. Up to $90 \%$ of the diatom assemblage is constituted by broken valves of different Pinnularia spp. Species of the genus Pinnularia can be found in a wide range of water types, but most of them are indicative of acid, oligotrophic fresh water (van Dam et al., 1994). The common diatom taxon Pinnularia lata lives in acidophilous fresh water and/or in moist aerial conditions (Krammer, 1992) or nearly exclusively outside water bodies (van Dam et al., 1994). Hantzschia amphioxys is quite cosmopolitan. It is able to live in the soil but more often in the spray or surf zones or in freshwater lakes. Eunotia praerupta prefers acid waters but it survives also in euterrestrial surroundings (Hustedt, 1959). Douglas \& Smol (1993) discussed that chrysophytes possess competitive advantage for nutrient uptake in oligotrophic ponds which are characterized by nutrient limitation, and the competition for nutrients between different algal groups plays a key role in their productivity. Siliceous phytoliths are inorganic supportingstructures found in some plants (Vuorela, 1991). The highest concentration of phytoliths is found in plants like Cyperaceae and Poaceae. In shoreline displacement studies sharp increases in the ratio of phytoliths to diatoms can indicate an offshore or even euterrestrial environment. The above supports the presumption that the sand directly underlying the pre-Litorina Sea organic layer was formed either in the spray zone of a beach of the regressive Ancylus Lake or, more likely, in a very shallow nutrient-poor pool which remained on the sandy coast of the retreating Ancylus Lake.

Once again the area emerged and organic sedimentation took place as a result of the regression of the Ancylus Lake. As Thomson (1928) and Kessel (1963, 1968) describe up to $1.32 \mathrm{~m}$ of gyttja and Phragmites-Carex fen peat $0.5 \mathrm{~km}$ upstream at Sindi (Fig. 2), we may presume that better drainage conditions existed at the edge of this bog at Paikuse and the organic matter here is therefore thinner and well decomposed. The vegetation type during the formation of that organic layer at Paikuse was Pinus-Alnus with abundant NAP, such as Poaceae, Cyperaceae, Filipendula, Rosaceae, Apiaceae, Typha angustifolia/Sparganium, Equisetum, all mainly indicative of a damp environment on mineral substrate.

During the formation of the upper organic layer, which indicates a terrestrial environment before the transgression of the Litorina Sea, conditions were too dry for the survival of diatoms. Diatoms in the thin sand layer under the upper organic layer (1.82-1.83 m) show that the shoreline of the Baltic Sea was not far from the Paikuse area. We do not want to make a conclusion that a minor transgression preceded the main transgression of the Litorina Sea. Southwestern Estonia belongs to the zone of very slow land uplift. As the area is very flat, then under the influence of a heavy storm the water level could rise several metres and the sea water could penetrate inland across the former river valley and inundate the place. Berglund \& Sandgren (1996), although, discuss possible brackishwater influence between 8800 and $8200 \mathrm{BP}$ during the transition from the Ancylus Lake to the Mastogloia Sea in Blekinge. The transition from the 
Ancylus Lake to the Litorina Sea, when the shoreline displacement was relatively small, minor deviations from the regular land uplift could also produce apparent transgressions in coastal basins (Hyvärinen, 1980).

A new rise in sea level is marked by the lithostratigraphical change from the upper organic layer to sand alternating with organic microlayers, seen in the Paikuse section. According to the ${ }^{14} \mathrm{C}$ date $7120 \pm 120 \mathrm{BP}$ obtained from the upper surface of the organic layer at a depth of $1.65 \mathrm{~m}$, the Litorina Sea transgression must have reached the area later than $7100 \mathrm{BP}$. The diatom assemblage with the freshwater Ancylus Lake flora and the presence of a few brackish-water diatom species is assumed to belong to the Mastogloia Sea phase. Similar diatom assemblages have been found at Rannametsa, $30 \mathrm{~km}$ south of Paikuse, where several ${ }^{14} \mathrm{C}$ dates from the peat reveal that the regression of the Ancylus Lake reached its minimum $c .8000 \mathrm{BP}$. The sandy gyttja and sandy silt overlying the peat at Rannametsa contain brackish-water (Campylodiscus clypeus, Campylodiscus echeneis, Diploneis smithii) as well as freshwater flora commonly occurring in the sediments of the Ancylus Lake (Ellerbeckia arenaria, Opephora martyi, Cocconeis disculus, Cocconeis placentula) (Hyvärinen et al., 1992). Hyvärinen (1984) reports comparable diatom records between 8000 and $7500 \mathrm{BP}$ in the littoral facies of the Mastogloia Sea stage from southern Finland. A slightly brackish transitional stage occurs also in the sublittoral sediments in the Gulf of Finland, southeast of Helsinki (Åker et al., 1988). The longer existence of slightly brackish-water conditions at Paikuse compared to the neighbouring regions is explained by the inflow of the Pärnu River into the lagoon which existed around Paikuse.

The disappearance of the Ancylus Lake flora and the progressive increase in brackish-water species marks the beginning of the Litorina Sea. The diatom assemblages of both the Mastogloia Sea and the Litorina Sea consist of periphytic diatoms, whereas planktonic species are almost missing. This indicates that the sedimentation took place in a shallow lagoon. In the uppermost sands of the Litorina Sea only diatoms with a robust structure like Diploneis interrupta are preserved with complete valves, while most of the diatoms occur as fragments. Vos \& de Wolf (1993) described Diploneis interrupta as a brackish-water aerophilous diatom, which is more frequently observed in the recent supratidal sediments in the Netherlands. Consequently, the waters of the Litorina Sea transgression submerged the Paikuse area for a short period and most of the upper part of the investigated sediment section formed already in the near-shore environment.

\section{ACKNOWLEDGEMENTS}

We are indebted to the following persons. Sirje Hiie, Institute of History, Tallinn, analysed some layers carpologically to extract suitable material for AMS 
dating. Göran Possnert, Uppsala University, and Arvi Liiva, Institute of Geology, University of Tartu, carried out the ${ }^{14} \mathrm{C}$ dating. Göran Possnert also added valuable comments on chronology. Leili Saarse, Institute of Geology, Tallinn, kindly allowed us to use some of her unpublished data. Anto Raukas, Institute of Geology, Tallinn, improved the manuscript with critical suggestions.

The research was financed by the Estonian Science Foundation (grant No. 2192) and Innovations for Development Association (IDEA) (grant "Diatom records and development of Estonian coastal lakes").

\section{REFERENCES}

Åker, K., Eriksson, B., Grönlund, T. \& Kankainen, T. 1988. Sediment stratigraphy in the northern Gulf of Finland. In The Baltic Sea (Winterhalter, B., ed.). Geol. Surv. Finland Spec. Pap., 6, 101-117.

Battarbee, R. W. 1986. Diatom analysis. In Handbook of Holocene Palaeoecology and Palaeohydrology (Berglund, B. E., ed.), pp. 527-570. John Wiley \& Sons, Chichester.

Berglund, B. E. \& Ralska-Jasiewiczowa, M. 1986. Pollen analysis and pollen diagrams. In Handbook of Holocene Palaeoecology and Palaeohydrology (Berglund, B. E., ed.), pp. 455-484. John Wiley \& Sons, Chichester.

Berglund, B. E. \& Sandgren, P. 1996. The early Littorina Sea environment in Blekinge chronology, transgressions, salinity and shore vegetation. Geol. Fören. Stockh. Förh., 188, A64-A65.

Douglas, M. S. V. \& Smol, J. P. 1993. Freshwater diatoms from high arctic ponds (Cape Herschel, Ellesmere Island, N.W.T.). Nova Hedwigia, 57, 3-4, 511-552.

Grimm, E. 1992. TILIA and TILIA GRAPH: Pollen spreadsheet and graphics program. In 8th International Palynological Congress. Aix-en-Provence, France, 56.

Haila, H. \& Raukas, A. 1992. Ancylus Lake. In Geology of the Gulf of Finland (Raukas, A. \& Hyvärinen, H., eds.), pp. 283-296. Estonian Academy of Sciences, Tallinn (in Russian).

Hustedt, F. 1959. Die Kieselalgen Deutschlands, Österreichs und der Schweiz unter Berücksichtigung der übrigen Länder Europas sowie der angrenzenden Meeresgebiete. In Dr. L. Rabenhorst's Kryptogamen-Flora von Deutschland, Österreich und der Schweiz. Vol. 7. Part 2. Reprinted by Koeltz Scientific Books, USA, 1991.

Hyvärinen, H. 1980. Relative sea-level changes near Helsinki, Southern Finland, during early Litorina times. Bull. Geol. Soc. Finland, 52, 2, 207-219.

Hyvärinen, H. 1984. The Mastogloia stage in the Baltic Sea history: Diatom evidence from Southern Finland. Bull. Geol. Soc. Finland, 56, 1-2, 99-115.

Hyvärinen, H., Raukas, A. \& Kessel, H. 1992. Mastogloia and Litorina Seas. In Geology of the Gulf of Finland (Raukas, A. \& Hyvärinen, H., eds.), pp. 296-312. Estonian Academy of Sciences, Tallinn (in Russian).

Ilves, E., Liiva, A. \& Punning, J.-M. 1974. Radiocarbon Method and its Application in Estonian Quaternary Geology and Archaeology. Academy of Sciences of the ESSR, Tallinn.

Jaanits, L. 1969. Eesti vanim asustus ja vanimad asukad. Eesti Loodus, 7, 410-414.

Kessel, H. 1963. Holocene coastal formations on the coast of southwest Estonia. ENSV TA Geol. Inst. Uurimused, XII, 123-144 (in Russian).

Kessel, H. 1968. Mattunud järve- ja soosetetest. Eesti Loodus, 1, 12-16. 
Kessel, H. \& Punning, J.-M. 1969a. Über das absolute Alter der holozänen Transgressionen der Ostsee in Estland. ENSV TA Toim. Keem. Geol., 18, 2, 140-153 (in Russian).

Kessel, H. \& Punning, J.-M. 1969b. Über die Verbreitung und Stratigraphie der Sedimente des Joldiameeres in Estland. ENSV TA Toim. Keem. Geol., 18, 2, 154-163 (in Russian).

Kessel, H. \& Punning, J.-M. 1974. About the age of the Ancylus Stage in Estonia (radiometric datings). ENSV TA Toim. Keem. Geol., 23, 1, 59-64 (in Russian).

Krammer, K. 1992. Pinnularia eine Monographie der europäischen Taxa. Bibliotheca Diatomologica, 26.

Punning, J.-M., Ilves, E., Liiva, A. \& Rinne, T. 1971. Tartu radiocarbon dates V. Radiocarbon, 13, $1,78-83$.

Punning, J.-M., Rajamäe, R., Ehrenpreis, M. \& Sarv, L. 1977. Tallinn radiocarbon dates IV. Radiocarbon, 19, 1, 111-117.

Raukas, A., Kimmel, K. \& Rajamäe, R. 1995a. A new site of buried peat at Lõpe, SW Estonia. Proc. Estonian Acad. Sci. Geol., 44, 2, 133-137.

Raukas, A., Moora, T. \& Karukäpp, R. 1995b. Läänemere arengust ja inimasustusest Pärnu ümbruses. In Liivimaa geoloogia (Meidla, T., Jõeleht, A., Kalm, V. \& Kirs, J., eds.), pp. 119-123. Tartu.

Selirand, J. \& Tõnisson, E. 1984. Through Past Millennia. Archaeological Discoveries in Estonia. Perioodika, Tallinn.

Thomson, P. W. 1928. Das geologische Alter der Kunda- und Pernaufunde. Vorl. Mitt. - Beitr. zur Kunde Estlands, XIV, 1, 1-11.

van Dam, H., Mertens, A. \& Sinkeldam, J. 1994. A coded checklist and ecological indicator values of freshwater diatoms from the Netherlands. Netherlands Journal of Aquatic Ecology, 28, $1,117-133$.

Veski, S. 1998. Early Holocene vegetation history and shoreline displacement of the Baltic Sea at the Mustjärve Bog, Northwest Estonia. Proc. Estonian Acad. Sci. Geol., 47, 1, 20-30.

Vos, P. C. \& de Wolf, H. 1993. Reconstruction of sedimentary environments in Holocene coastal deposits of the southwest Netherlands; the Poortvliet boring, a case study of palaeoenvironmental diatom research. Hydrobiologia, 269/270, 297-306.

Vuorela, I. 1991. Phytolith analysis as part of the study in Helsinki old town. In Current Research 1989-1990 (Autio, S., ed.). Geol. Surv. Finland Spec. Pap., 12, 143-146.

\title{
PAIKUSE (EDELA-EESTI) KAHE MATTUNUD ORGAANIKAKIHI BIO- JA KRONOSTRATIGRAAFIA
}

\author{
Atko HEINSALU, Siim VESKI ja Tanel MOORA
}

Setete õietolmu ja diatomee analüüsi ning radiosüsiniku meetodi abil uuriti kahte Paikuselt leitud mattunud orgaanikakihti. Alumine turbakiht moodustus preboreaalis umbes 130 -aastase ajavahemiku jooksul. Antsülusjärve transgressiooni tagajärjel mattusid uuritud piirkonnas orgaanilised setted $1,5 \mathrm{~m}$ paksuse liivakihi alla hiljem kui 9350 aastat tagasi. Ülemine mattunud orgaanikakiht moodustus, kui Antsülusjärve veetase oli alanenud, ning see ujutati taas üle umbes 7100 aastat tagasi riimveelise Litoriinamere poolt. 


\title{
БИО- И ХРОНОСТРАТИГРАФИЯ ДВУХСЛОЙНОЙ ПОГРЕБЕННОЙ ОРГАНИКИ В ОКРЕСТНОСТЯХ ПАЙКУЗЕ, ЮГО-ЗАПАДНАЯ ЭСТОНИЯ
}

\author{
Атко ХЕЙНСАЛУ, СиЙм ВЕСКИ и Танел МООРА
}

Изучены двухслойные погребенные отложения в окрестностях Пайкузе по данным спорово-пыльцевого анализа, а также диатомовых и радиоуглеродных датировок. Установлено, что формирование нижнего слоя торфа происходило в пребореале, на протяжении примерно 130 лет. Во времена трансгрессии Анцилового озера органогенные отложения оказались погребенными песками мощностью около 1,5 м позднее 9350 лет т. н. Верхний слой органики формировался в ходе регрессии Анцилового озера и был погребен водами Литоринового моря примерно 7100 лет т. н. 